\title{
"Seoul-searching": The 2010 G-20 Seoul Summit
}

\author{
曲
}

\author{
Judith Cherry and Hugo Dobson
}

\begin{abstract}
The Group of 20 summit of developed and developing countries-the selfappointed "premier forum for international economic cooperation"-met in the South Korean capital in November 2010. This was a watershed event in that it was the first time for the G-20 to meet in an Asian, non-G8 country. This article evaluates the success of the Seoul summit against a range of criteria and from various perspectives, in addition to commenting on the appropriateness of these criteria in measuring the performance of future summits. KEYWORDS: G8, G-20, summit conferences.
\end{abstract}

THE FIFTH Group of 20 (G-20) LeAders' SUMmit-THE SELF-APPOINTED "premier forum for international economic cooperation"-met from 11 to 12 November 2010 in Seoul, South Korea. In the relatively brief history of G-20 summitry, this remains a significant summit in a number of ways. It is the only G-20 summit to be hosted in Asia (before Seoul, summits were held in Washington, London, Pittsburgh, and Toronto on a biannual basis; after Seoul, the G-20 gathered in Cannes and moved to meeting on an annual basis), and remains the only time a non-Group of 8 (G8) country has hosted the G-20. For the hosts, this was an opportunity to both demonstrate leadership in the international community and take pride in staging a successful global event ranking alongside the 1988 Olympics and 2002 Soccer World Cup. On a different level, the agenda of the summit was replete with pressing issues from currency disputes to financial safety nets via the expansion of the G-20's agenda to include issues such as development through to the reform of the International Monetary Fund (IMF), the evolving architecture of global governance, and the G-20's position therein as it metamorphosed into an emerging global steering committee from a crisis committee. In short, both the Korean hosts and the international community placed high (and possibly unrealistic) expectations on Seoul as an opportunity to address a wide range of issues.

A year later, in November 2011, the Cannes summit regularized the future hosting of G-20 summits. As a result, Mexico will act as a first-time host in June 2012; thereafter, Russia will assume the presidency in 2013, Australia in 2014, and Turkey in 2015. After 2015, the rotation will be decided within regional groupings, beginning with Asia comprising China, 
Indonesia, Korea, and Japan. Thus, G8 countries, which have dominated the G-20 process so far, will host fewer summits and non-G8 countries will assume considerable influence in deciding the direction of the G-20 summit process. In light of these developments, the Seoul summit stands out as a benchmark of what we might expect of the newcomers to "G" summitry in terms of their style of hosting, underlying motivations, and contribution to meeting the challenges of global governance. With the goal of gleaning lessons for the future, we assess the performance of the Seoul summit from a variety of perspectives as this (and any) summit has different meanings for different actors. We do this by applying criteria from the extant literature that not only evaluate the summit outcomes but also bring the host's motivations into relief, suggesting that factors such as domestic political enhancement and national branding were of greatest importance. However, we first present these criteria for measuring the success or failure of individual summits.

\section{Measuring Summit Success}

The question of how to measure the success of a summit, whatever the alphanumeric configuration, is a contentious issue. For a long time, Robert Putnam and Nicholas Bayne's Hanging Together: Cooperation and Conflict in the Seven-Power Summits offered the only measure of summit success, based on the four criteria of "mutual enlightenment (sharing information about national policy directions), mutual reinforcement (helping one another to pursue desirable policies in the face of domestic resistance), mutual adjustment (seeking to accommodate or ameliorate policy divergences) and mutual concession (agreeing on a joint package of national policies designed to raise the collective welfare)."1

Building on this foundation, John Kirton relabeled the criteria for success as "leadership education," "political direction," "policy co-ordination," and "socio-economic management." In addition, he added "domestic political enhancement." 2 Over many decades, hosts have instrumentalized G8, and most recently G-20, summits in order to enhance domestic standing. US president Gerald Ford unexpectedly called the second summit of the Group of 7 (G7) in San Juan in 1976 with one eye on the presidential election of that year. Over thirty years later, UK prime minister Gordon Brown was able to bolster momentarily flagging domestic support by hosting the G-20 summit in London and attempting to exhibit international statesmanship.

Thereafter, Nicholas Bayne increased these criteria to six: leadership, effectiveness, solidarity, durability, acceptability, and consistency. Leadership "judges how far summitry was able to exercise its political authority ... to resolve disputes that had been blocked at lower levels and overcome bureaucratic inertia or deadlock. It could also . . impart decisive momentum to new ideas and initiatives." Effectiveness "assesses the summits' abil- 
ity to reconcile the tensions between different pressures on the member governments, so as to reach agreement." Solidarity "considers whether all the G8 countries were committed to the decisions taken at the summit, so that they could be fully implemented." Durability "tests whether the agreement reached at the summit produced a lasting solution to the problem [recognizing] that summits were no longer isolated events, but part of a regular institutional series." Acceptability "examines whether the solutions reached at the summit commanded the support not only of the G8 members but also of the world community as a whole ... [reflecting] the growing number of actors in the international system caused by the advance of globalization." And consistency "is concerned with whether G8 decisions in one policy area, such as finance, fitted in with the policies the G8 adopted on other subjects, like trade or development. This criterion . . . had become harder to meet as the G8 agenda had expanded."3

Certainly, there is a degree of overlap in these various criteria. However, for the purposes of this article, we adopt Bayne's six criteria as the yardstick most appropriate to the way in which G8 and, by extension, G20 summitry function, as informal and flexible fora for the iterative treatment of issues and coordination of interests among the leading powers of the day. Crucially, we include Kirton's criterion of "domestic political enhancement" to ensure that the perspective of the host and its own immediate objectives in hosting a summit are brought into the analysis.

Admittedly, the applicability and transferability of these criteria are questionable as they have emerged from decades of evaluating G8 summits. However, as the genesis, nature, and function of the G8 and G-20 display a high level of similarity, we assume initially that these analytical criteria are appropriate before commenting in the conclusion on the need for their refinement in continuing to assess future G-20 summits.

\section{Leadership}

Ahead of the Seoul summit, the question of leadership was of central concern for the Korean hosts as seen in the words of SaKong Il, head of the G20 Summit Coordinating Committee: "The G-20 members, especially the G7, know we'll be more than willing to lead. Leadership doesn't mean working alone. Leadership means getting harmony, getting cooperation and getting support."4 Previously, he had outlined Korea's leadership qualifications that stressed its position as a bridge between the developed and developing economies because of its membership in the Organisation for Economic Co-operation and Development (OECD) and its own recent experience of development. ${ }^{5}$

Korea's credentials were strengthened by its ability to weather the global financial crisis as one of only three OECD member countries recording positive economic growth in 2009 , the only export-led economy to finish the year in the black, and the first country to move from aid recipient 
to donor since the establishment of the OECD. To be sure, ahead of the summit, reservations had been expressed about Korea's suitability to host and lead in the G-20. ${ }^{6}$ Thus, Korea's concern was to demonstrate to the world the summit's ability to exercise political authority to give impetus to or make breakthroughs on specific issues, in line with Bayne's first criterion of summit success.

Leadership can be gauged both in terms of concrete agenda items and the overall momentum and future direction of the G-20 process. The Seoul summit's agenda consisted of legacy issues and new issues; in other words, issues ongoing from previous summits that required Korean guidance in addition to the opportunity for Korea to add to the agenda of Seoul and future summits.

With regard to legacy issues, progress on IMF reform was certainly evident in the Seoul Summit Document that reiterated agreements reached at the G-20 finance ministers' meeting held on 23 October 2010 in Kyongju to increase the representation of developing countries and thereby strengthen the institution itself. Concretely, by the end of 2012, European representation on the twenty-four-member board of the IMF will decrease from eight seats to six seats; 6 percent of voting power will be redistributed to the underrepresented, leaving China ranked third in voting rights and catapulting Brazil, India, and Russia into the top ten. Although member countries still have to approve these agreements, the reforms were initially hailed by IMF managing director Dominique Strauss-Kahn as "the most important reform in the governance of the institution since its creation." "7

The banking reform package, dubbed the "Basel III code" was finalized at the summit for endorsement by the central banks and financial regulators of the member nations, with the aim of "making banks safer and bankers less adventurous with their customers' (and taxpayers') money." 8 In October 2011, the Bank of International Settlements published its first progress report on Basel III implementation, listing the status of the adoption of the Basel regulatory capital framework in member countries. Of the twenty-eight countries surveyed (including individual European Union [EU] member states), sixteen had not yet published draft regulations, eleven had published draft regulations, and one had published final rules but they were not yet in force. This stage was in preparation for the review in 2012 of the consistency of national rules and regulations with the minimum standards required by the Basel III code. ${ }^{9}$

Despite the suppression of protectionism being perceived by some as "the most critical task related to the G-20" and the fact that success in that area would have significant benefits for the Korean economy in which exports accounted for 43.4 percent of gross domestic product (GDP), progress in this area was modest. ${ }^{10}$ Similarly, although a commitment was made to conclude the deadlocked Doha Development Agenda (DDA) in 
2011, no progress was made. In fact, the Cannes summit admitted to past failures, called for fresh and credible approaches, and warned that the DDA will not be completed if negotiations continued in the same vein. ${ }^{11}$

With regard to new issues that shape the future direction of the G-20, the Korean hosts took a balanced and sober approach by prioritizing key issues and limiting others. Instead of adding other heavyweight issues such as climate change, the Korean government emphasized growth-oriented development, new financial safety nets, and regularizing G-20 outreach, grouped together under the label of "Korean Initiatives." However, the "Korean-ness" of these initiatives is open to question and, although presented as a new agenda item, development had already appeared on the agenda of the Toronto summit earlier in 2010 and resulted in the creation of the Development Working Group (DWG), chaired by South Africa and South Korea.

Specifically on this issue of development, Korea had been pressing for its inclusion on the G-20's agenda for some years. President Lee Myungbak stated ahead of the 2009 Pittsburgh summit that: "The G-20 leaders should pay special attention to the needs and causes of emerging and developing countries." 12 To this end the Seoul Summit Leaders' Declaration highlighted the Seoul Development Consensus for Shared Growth, its aims, and emphasis on concrete measures as summarized in the Multi-Year Action Plan (MYAP) on Development. ${ }^{13}$

The MYAP outlined a number of principles to support resilient and shared growth that to an extent replaced the Washington Consensus with a Seoul Consensus and shifted the focus to these principles rather than financial contributions. The DWG met twice in 2011 and presented its first annual report at the Cannes summit, in which it stated that the group had started implementing the MYAP by "taking both individual and collective actions along two avenues: setting the foundations for strong and balanced growth and building resilience." Looking forward to 2012, the DWG plans to focus on a small number of high priorities while monitoring past actions, "with a view to maximum progress on the Seoul Multi-Year Action Plan in the coming years." 14 However, the role that Korea can play in promoting development is questionable; Thomas Kalinowski has argued that Korea has failed to offer an alternative model and instead has promoted a highly selective and sanitized version of its own development. ${ }^{15}$

On the foreign exchange rate issue, which emerged before the summit and centered on tensions between the United States and China over the value of the yuan, Lee admitted at the end of the summit that principles were established at the finance ministers' meeting in Kyongju. At the Seoul summit, leaders agreed to avoid "competitive devaluation of currencies" and establish a set of "indicative guidelines" during 2011 that could identify economic imbalances and the actions needed to fix them. ${ }^{16}$ Thus, a 
multilateral rather than bilateral approach was promoted and resulted in the establishment at the G-20 finance ministers meeting in Washington, DC, in April 2011 of guidelines to measure the potential risks to the global economy posed by national economic policies. Then, in May, Korea was selected as the chair of a task force mandated by the G-20 to review issues such as the management of capital flows and foreign exchange risks that are a potential danger to emerging markets and developing economies and to discuss how to maintain a prudential oversight of global financial institutions. ${ }^{17}$ Nevertheless, tensions between the United States and China rumbled on in 2011; in October, the US Senate passed a bill calling for the imposition of tariffs on Chinese imports in response to China's alleged actions to keep the yuan artificially undervalued. ${ }^{18}$ Thus, the Korean hosts demonstrated a mixed record in terms of leadership, making progress in some, but not all, legacy issues while promoting new issues that are still ongoing.

\section{Effectiveness}

Effectiveness is concerned with negotiating and reaching agreement in light of the various pressures faced by each summit nation. For example, although South Korea placed great emphasis on the value of its own experiences in guiding other countries along the development path, officials made it clear that it would not be promoting its own growth model. Efforts by successive governments to foster economic growth by a combination of measures to protect infant domestic industries and restrict the participation of foreign companies in the local economy gave Korea a reputation for protectionism that did not sit well with its aim of proving its potential as a global leader. Instead, Korea chose to tone down this aspect and instead emphasize the crucial role played by elements such as infrastructure, human resource development, and education in the growth and development processes. ${ }^{19}$ Thus, as hosts, the Korean government compromised on the promotion of its own agenda in order to facilitate a statement to which fellow summiteers could agree.

\section{Solidarity}

Solidarity is concerned with the unity of the G-20 countries in achieving the summit's goal of collective management of specific issues. Considerable expectation of Korea's role was in evidence after divisions appeared to emerge at the G-20 Toronto summit in June 2010, where it was agreed to disagree on deficit reduction and an agreement on a global bank levy was shelved. Moreover, in the immediate run-up to the Seoul summit, media attention was firmly focused on the potential for "currency wars" to drive divisions between the summit leaders and damage the overall cohesion of the G-20. In particular, the US-China standoff on the value of the yuan and 
the second round of quantitative easing in the United States appeared to augur badly and point toward mutual recrimination. This was brought into stark relief when on 29 September 2010 the US House of Representatives approved punitive measures against China. Certainly, President Barack Obama's public criticism of China's undervalued currency immediately after the Seoul summit's joint statements were released contributed little to a sense of solidarity. Nevertheless, as mentioned above, although it was not Korea that mediated, the leaders were able to leave Seoul with enough reason for all sides to claim victory.

One aspect of solidarity that presents South Korea with a quandary is the degree to which it seeks to cast itself in the role of the representative of Asia in the G-20 (a role previously cherished by Japan in the G8). Although promoting Asian solidarity might provide a defining role for South Korea, especially as the first Asian host, this could serve to work against the solidarity of the G-20 overall and replicate the factionalism that exists within the United Nations. In this regard, rather than stressing the solidarity of Asian members of the G-20, the Korean government toned down any regional leadership ambitions in favor of fulfilling the criterion of solidarity.

However, just two weeks after the Seoul summit ended, the Korea Institute for Economic Policy (KIEP), a state-run think tank, published a report expressing "real concerns that Korea could experience a dramatic decrease in influence in the G-20." In contrast to reliance on its economic power, the report recommended Korea's assumption of a leadership role in terms of both its intellectual contribution and fostering cohesion among Asian members. ${ }^{20}$ Thereafter, in a press interview in March 2011, Sohn Byung-doo, director general of the newly created G-20 Bureau (within the Ministry of Finance) declared that the Seoul summit had allowed Korea to make the transition from being a rule follower to a rule setter. Sohn emphasized Korea's role as a bridge builder and trusted regional partner in communicating with China. ${ }^{21}$ With the scheduling of future summits having now been decided at the Cannes summit, this increased sense of regional identity and need to coordinate may begin to emerge and challenge the G-20's solidarity. ${ }^{22}$

\section{Durability}

The problem with applying the criterion of durability is that, after just over one year, it may be too early to do so productively. Nevertheless, with regard to the host's intentions, it is clear that durability was at the heart of its approach to the Seoul summit as captured by its motto of "shared growth beyond crisis." 23 The Korean hosts were also looking ahead to the future of G-20 summitry aware of the fact that Seoul was the last summit before it adopted an annual, rather than biannual, schedule, thereby allowing Korea to provide a steer to future summits. 
In this context, SaKong expressed the personal hope that, having guided the global economy out of the current crisis, the G-20 would evolve into a global steering committee, representing "a more promising and legitimate architecture for cooperation than has existed for many years." He also promised that Korea would cooperate with its global partners to make the G-20 an "effective and durable" permanent institution with a lean, small and efficient secretariat. ${ }^{24}$ Although a G-20 secretariat has yet to emerge and is a moot point, by introducing country-specific undertakings backed up with monitoring and transparency, the G-20 took a step toward greater institutionalization. Furthermore, the regularization of the Business 20 (B20) summit, held for the first time in Seoul at the suggestion of the Korean government, created a meeting of the chief executive officers of the world's leading corporations and gave the private sector a voice in the debate on the future of the global economy. ${ }^{25}$ This was replicated by the French hosts in 2011 in line with Korea's intention for this to become a permanent feature of the summit process.

The G-20 Seoul Speakers' Consultation, which was hosted by the National Assembly in May 2011, provided another aspect in which Korea continued to work for the institutionalization of the G-20 process. Although originally a one-off gathering of parliamentary leaders held in Ottawa in 2010, Park Hee-Tae, speaker of the Korean National Assembly, proposed regularizing the meeting. Thus, for Korea, success was closely related to ensuring the durability of the G-20 as the central institution of the architecture of global governance and Korea's role therein.

In addition, a number of concrete deliverables have the potential to create a durable Korean legacy within the G-20. First, with regard to reform of the international financial sector, writing before the summit SaKong noted that the recent global financial crisis had "provided painful evidence that the International Financial Institutions (IFIs) were not equipped to conduct proper surveillance and provide early warning of macroeconomic or financial risks." 26 So far-reaching were the changes to capital and liquidity regulations that South Korean deputy finance minister Shin Je-yoon proposed changing the name of the code from "Basel III" to "Seoul I"- - a proposal that would ensure a lasting legacy for South Korea from the 2010 summit. $^{27}$ Second, the Samsung Economic Research Institute (SERI) went further by proposing that the Seoul Consensus within the G-20 replace the Washington Consensus that had dominated the global economic order from the 1980s. At the core of the Seoul Consensus is "the pursuit for [sic] an effective and fair distribution of resources and a sustainable and balanced growth of the world economy through the close cooperation between the advanced and developing countries." 28

Reform of the IMF and the World Bank provides further potential for a durable legacy of the Seoul summit. Facing criticism that it was not able to halt the spread of financial crises, the IMF had acknowledged the need 
for reforms in its governance ahead of the summit. In this light, it was noted that a Korean official had called for an increase in analysts within the IMF who were not "macro-economists with degrees from an Ivy League school." 29 Noting the convention that a European fills the position of IMF managing director and a North American leads the World Bank, one Korean newspaper argued that the appointment of an Asian managing director might help to "improve the somewhat negative image of the IMF in the region." 30 However, with the appointment of Christine Lagarde in July 2011, convention won out and an opportunity was lost.

France's presidency of the G-20 was informed by goals set at the Seoul summit such as the agreement on improving the G-20's Mutual Assessment Process to promote macroeconomic cooperation and avoid a repeat of the global economic crisis through the establishment of "indicative guidelines" for quantifying imbalances. Thus, as mentioned above, the G-20 announced in April 2011 four methods of monitoring imbalances: using countryspecific models to estimate what a country's imbalances should be; looking at historical imbalances; comparing a country's imbalances with groups of similar countries; and comparing a country's imbalances with the full G-20. ${ }^{31}$ However, in the documentation issued at the end of the Cannes summit, the "Cannes Action Plan for Growth and Jobs" simply stated that "we have met our Seoul commitment to develop indicative guidelines to assess persistently large imbalances," and mention of the success or failure of this initiative in the Final Declaration was limited to the brief sentence: "Global imbalances persist." 32

On May 14, South Korean president Lee Myung-bak and French president Nicolas Sarkozy issued a joint statement in which they agreed to work in close cooperation in order to allow the G-20 to deliver on its commitments. In addition, Sarkozy added his own agenda items, including development, innovative financing, employment and social issues, and addressing volatility in food and fuel prices. ${ }^{33}$ Although the Cannes summit and many of these agenda items were eclipsed by events in the Eurozone, and Greece in particular, progress continued in areas such as the Basel III code, the MYAP, and "indicative guidelines."

\section{Acceptability}

Acceptability entails securing the support of both fellow summiteers and the outside world as represented by a range of stakeholders from business groups to civil society and the global media to public opinion. Within the G-20, interim compliance reports ${ }^{34}$ conducted by the University of Toronto's G-20 Research Group demonstrate that the Seoul summit resulted in higher levels of compliance with declared commitments than the Toronto summit and a closing gap in compliance and noncompliance between G8 and G-20 countries respectively, suggesting increased acceptability and solidarity. 
Outside of the G-20, the Korean government engaged in extensive outreach activities prior to the summit to canvass the opinions and concerns of these countries, appointing the deputy minister for foreign affairs Ahn Ho-Young as the G-20 ambassador at large for outreach activities. The South Korean government invited five non-G-20 member countries and seven global organizations to the meeting; these invitations reflected the proposed focus on developing and emerging economies with Malawi (chair of the African Union), Ethiopia (chair of the New Partnership for Africa's Development), Vietnam (chair of the Association of Southeast Asian Nations [ASEAN]), and Singapore (chair of the Global Governance Group) being selected. Spain was the fifth non-G-20 member to be invited, reflecting its status as one of the ten largest economies in the world and as a participant in previous G-20 summits. Seven international organizations invited were: the UN, the International Labour Organization, the World Bank, the IMF, the OECD, the World Trade Organization (WTO), and the Financial Stability Board. The only absentee was King Abdullah bin Abdul Aziz Al Saud of Saudi Arabia.

Thus, the Korean government's intentions to enhance acceptability through outreach were realized in terms of attendance. Moreover, they were also reflected in the Seoul Summit Document, which established principles that have been adopted on the future participation of non-G-20 countries by which no more than five would be invited and at least two of which must be African. ${ }^{35}$ The above-mentioned B20 can also be regarded as part of this process of securing a broad consensus among a range of stakeholders.

However, acceptance was not as evident in the vernacular press, with one leading newspaper claiming the outcomes left "something to be desired." 36 The Korea Times and Korea Herald noted that the "difficult details" underlying the broad statement of principles agreed on at the G-20 had been left as "homework" to be sorted out later and warned (incorrectly) that there was no guarantee that the G-20 would agree on the specific details by the deadline of June 2011. ${ }^{37}$ Threatening the future of the G-20 itself, the Chosun Ilbo warned that "consensus about the economic crisis and a sense of urgency among G-20 countries are diminishing." 38

With regard to civil society, protests began in earnest on the Sunday before the summit, when tens of thousands of demonstrators gathered in front of Seoul City Hall voicing their opposition to the G-20 summit, globalization, and Korea's free-trade agreement with the United States. This demonstration was ultimately "peaceful, almost festive." 39 On the first day of the summit, the Korean People's G-20 Response Action, incorporating some eighty progressive civic groups, political campaigners, college students, and human rights activists, held a mainly peaceful rally through the downtown area. ${ }^{40}$ However, after the summit, it emerged that many of the demonstrations that had been planned did not take place, either because the 
organizers canceled them voluntarily or because the police banned them. ${ }^{41}$ Ultimately, any fears of violent protest proved unfounded; although this does not necessarily denote acceptance of the summit's outcomes, it does suggest that the Korean people's attention was focused elsewhere.

\section{Consistency}

The more limited the range of issues, the easier it is to ensure a degree of consistency across them. At its current stage of development, the G-20's attention is focused on the core issues related to the global economic crisis. However, as it metamorphoses from a crisis committee into a global steering committee, the G-20's agenda will inevitably expand along the same lines as the G8.

As mentioned above, the agenda for the Seoul summit could be divided into two main areas: reviewing the agreements from the past four summit meetings and formulating strategies for their implementation; and, for the Korean hosts, developing new items for the evolving agenda, with a particular focus on topics relevant to developing and emerging economies. These new agenda items were addressed under the discussion of leadership but, in terms of consistency, some warned against having too ambitious an agenda and emphasized the need for a "pragmatic, feasible and uncontroversial agenda that could be acceptable to the G-20 members." 42 Thus, the tensions between a consistent and limited agenda and an unwieldy wideranging one were all too clear to the Korean hosts.

Linkage to the Cannes summit and the creation of legacy issues for the French was also evident, specifically in a broader reform of the institutions of global governance as well as promoting innovative financing for development and climate change to the agenda of the Cannes summit. Despite the addition of legacy issues to an expanding agenda, the future institutionalization of the G-20 ought to facilitate a higher degree of consistency, and core to this will be the issue of whether or not a G-20 secretariat is created. ${ }^{43}$ For the time being, however, institutionalization remains an item for discussion not action.

\section{Domestic Political Enhancement}

The previous criteria focus on measuring summit success in the context of the challenges of global governance. However, in a number of respects, the Korean government used the Seoul summit for domestic ends or national interests that were seemingly unrelated to the business of G-20 summitry. For example, and although ultimately unsuccessful, the summit provided a deadline to attempt the conclusion of the Korea-US free-trade agreement, which had stagnated at the ratification stage for more than three years due to opposition in both legislatures. The summit was also seen as a potential means to secure greater leverage with North Korea and, in the event of uni- 
fication, attract assistance from multilateral institutions to ease the associated economic burdens, although ultimately no mention was made of North Korea in the final summit documentation. ${ }^{44}$

Similarly, a successful summit can have short-term economic benefits. According to SERI, the short-term economic gains associated with hosting a successful G-20 summit could be as high as US\$20.6 billion for Korea. In addition to direct short-term effects such as revenues from consumer and tourist spending, the effect of the enhancement of Korea's national and corporate brands would be equivalent to expenditures of $\$ 1.5$ billion on advertising, with a resulting increase of $\$ 16.2$ billion in corporate revenues. ${ }^{45}$

However, the instrumentalization of the summit for domestic ends was more evident with regard to the issues of presidential legacy. Since the 1980s, the constitutional ban on South Korean presidents serving more than one term of office has put successive leaders under pressure to create a significant legacy by making bold decisions and actions during their limited term as president. Roh Tae-woo (1987-1993) restored diplomatic relations with the Soviet Union and the People's Republic of China; Kim Young-sam (1993-1998) secured OECD membership for Korea; and Kim Dae-jung (1998-2003) steered Korea through the "IMF Crisis" and was awarded the Nobel Peace Prize for his efforts to secure democracy in the South and ease tensions with the North.

Prospects for Lee's "747" election pledge for his presidency-an annual increase in GDP of 7 percent, a doubling of per capita annual income to $\$ 40,000$ within a decade, and the elevation of South Korea from the eleventh to the seventh largest economy in the world-were considerably weakened by the outbreak of the global economic crisis. However, hosting the G-20 offered Lee the opportunity to make a significant contribution to his own legacy by moving Korea to the forefront of global governance and burnishing the nation's brand. Following the 2008 Washington summit, the Lee administration engaged in an "aggressive," "passionate," and, ultimately, successful diplomatic campaign to secure the chairmanship of the G-20, frustrating Japan's ambitions in the process. ${ }^{46}$ After the summit, Lee linked the successful hosting of the forum to the fortunes of the Korean people: "The success of the G-20 summit is the people's success and the country's success. If, at times like this when our national fortunes are on the rise, we unite and move forward, we will certainly become a first-class nation leading the world." ${ }^{47}$

Thus, the summit's and South Korea's success were inevitably linked, and the hosts pursed national interest and global leadership hand in hand. In particular, these two goals coalesced around overcoming "misleading and outdated perceptions" of Korea and its often negative image overseas and demonstrating the country's qualifications for global leadership in terms of its "experience and expertise ... on strategies for development and on policies for successful recovery from financial crises." 48 South Korea's foreign 
minister Yu Myung-hwan saw the summit as a "chance to upgrade our country's status in the international community." 49 Whereas the Financial Services Commission expressed its hopes that chairing the summit would result in a switch from what it termed the "Korea discount" effect (which had led in the past to the undervaluing of the Korean economy in the global market) to a "Korea premium effect." 50 For others, the summit provided a "checkpoint to see what kind of achievements we have and what kind of tasks lie ahead," emphasizing its impact both in terms of enhancing Korea's global image and also encouraging and stimulating the Korean people themselves. ${ }^{51}$ In any case, hosting a successful summit offered Korea the opportunity to establish a central position in the international community and demonstrate the extent of its recovery from the traumas and reputational damage of economic collapse at the end of the 1990s.

In a similar vein, the media's evaluation combined a sense of pride in Korea's success as host and a sense of need for the government to maintain the momentum generated by hosting the summit. The Chosun Ilbo declared that the greatest legacies of the summit were Korea's demonstration of leadership and its proven ability to "play a central role in global diplomacy," but also highlighted the boost to national confidence. ${ }^{52}$ The Korea Times summarized the consensus among foreign correspondents that "Korea proved itself to be a skilful economic and diplomatic player on the global stage. ... Korea is no underdog. It is no longer a small power that can be swayed by bigger or more aggressive neighbors. It is a medium strategic power with the ability to participate in the global agenda, and it should think like one." ${ }^{53}$ Korea was now speaking up on a variety of global issues and, as a result of the G-20 summit, had a voice in global governance.

In a survey conducted by the Presidential Council on Nation Branding and SERI in December 2009, Korea was ranked nineteenth of thirty OECD member countries in terms of national branding. SERI forecast an improvement after the summit in the areas where Korea's weaknesses had contributed to its low ranking: "policy and diplomacy" (ranked twenty-fifth) through demonstrations of global leadership; "traditional culture" and "contemporary culture brand" (twenty-fifth and twentieth, respectively) through increased international media attention; and "citizens" (twentieth) through improving the Koreans' global mindset and self-esteem. ${ }^{54}$

The above-mentioned G-20 Seoul Speakers' Consultation provided an opportunity to continue the process of national branding. As part of the meeting, a Korean luncheon was served by staff in traditional Korean dress and held in a traditional Korean house, specially constructed in the courtyard of the National Assembly. Park Hee-tae captured the inward and outward nature of this national branding by hoping that the "guests will return home after experiencing many different aspects of our beautiful culture [and that] Korean people abroad can take pride in the fact that our country now plays host to these important meetings." 55 
Another example of domestic political enhancement through successful summitry was seen in the adoption of the Seoul Consensus. As mentioned above, it was seen to present a different approach from the market-oriented Washington Consensus. In so doing, Korea would draw on its own experience of rapid economic development and provide lessons that, according to one Korean journalist, "rich countries will never be able to give to poor countries." 56 The Chosun Ilbo hailed the Seoul Consensus as the first step in the presentation of Korean- or Asian-style development models as new global standards to be tested in Latin America and Africa. If successful, the Seoul Consensus could consign the "development models used so far" to the rubbish bin. ${ }^{57}$ Within Korea, this represents an irony that would not have been lost on the Koreans who had been pulled into line with the principles of the Washington Consensus as a condition of the IMF bailout in 1997. For the Korean hosts, this particular outcome was a significant achievement on the national level.

An opinion poll conducted in autumn 2010 supports these analyses of the most important benefits of a successful summit: a majority of 41.8 percent of respondents felt that hosting G-20 was an opportunity for Korea to promote its image abroad and that it would increase the nation's standing in international society; 35.3 percent felt that Korea would benefit in economic terms from hosting the event. ${ }^{58}$ Korea's efforts to enhance its national brand appeared to bear fruit when in July 2011 Pyeongchang was selected in the first round of voting to host the 2018 Winter Olympics. This will be the first time that the Winter Olympics will be held in Asia in the twenty-first century.

\section{Conclusion}

Returning to our original objectives, applying these seven criteria to the Seoul summit presents something of a mixed bag in terms of the success of the summit for the G-20, the international community, and the Korean hosts. In terms of Bayne's six criteria that measure summit success from the viewpoint of the international community, the G-20 achieved progress in some areas (institutionalization of and outreach from the G-20), has still to realize its potential (IMF reform), but made no headway in others (the DDA). It can claim varying degrees of success in providing leadership on both legacy and new issues, reconciling tensions in order to ensure the summit's effectiveness, bolstering the solidarity of the summiteers, introducing measures that have been durable, promoting acceptability through new initiatives, and acting with sensitivity toward maintaining consistency across the summit's agreements. The Korean government sought and managed for the most part to play an active role in all of these areas.

The seventh criterion of domestic political enhancement, however, measures success from the limited perspective of individual leaders and 
countries and, in the specific case of Korea, represents more of a motivation in seeking to satisfy the other criteria. In his New Year's address to the Korean people, Lee reflected on the highlights of the past year, giving first mention to the G-20 summit: "The Republic of Korea was able to stand tall in the international arena by hosting the G-20 Seoul summit. Korea has now emerged as a nation that helps to establish the international order, rather than always having to follow others."

The year 2010 was seen to be a "truly memorable year" in that Korea had overcome the economic crisis, posted the highest economic growth rate of any OECD member country, and become the seventh largest exporting nation in the world. In the coming decade, Lee promised that Korea would build on these achievements and "rise to an advanced, leading country in both name and reality." He reflected on Korea's proposal to the G-20 for a development agenda and looked forward, calling the young people of Korea the "G-20 Generation [G-iship Sedae]" who should be nurtured as "protagonists for building a leading global nation." Concluding his speech, Lee urged his people to "join forces and unite" and seize the opportunity presented by the achievements of 2010 "for the country to shine in the community of nations . . . to leap over the threshold and become an advanced nation." 59

From the focus and tone of the presidential speech, it is clear that the successful hosting of the G-20 summit was regarded by the government as an important stepping stone toward the completion of Korea's transformation from a war-ravaged, economically impotent country in the 1950 s to an advanced nation, economic powerhouse, and leader of the global community in the twenty-first century.

Lee is likely to be judged, as his predecessors have been, on the country's economic performance and developments in North-South relations during his term of office. So, the successful lobbying to chair the G-20, the smooth running of the summit, and the creation of a legacy for Korea within the G-20 are unlikely to contribute significantly to Lee's presidential legacy per se. Nevertheless, the motivations in hosting the summit are clear: providing key concrete deliverables while establishing a leadership role for Korea in the central institution of global governance and boosting national confidence. Thus, a similar focus on domestic political enhancement and national branding can be expected from future first-time hosts eager to establish their leadership credentials, although it would be naïve and patronizing to suggest that only first-time hosts are subject to this temptation.

With regard to the relevance of these criteria for measuring summit success, one assumption implicit in these criteria is that summits take place according to a preordained agenda and are almost impervious to outside events. In reality, as the Cannes summit shows clearly, the summit is often hostage to fortune and this aspect needs to be included in the criteria 
employed to evaluate future summits. In addition, a degree of mutual reinforcement across these seven measures is apparent, with the most obvious synergy existing among leadership, acceptability, effectiveness, and domestic political enhancement. In addition, durability presents specific problems in its measurement when evaluating a summit at this early stage. Considering the future of the G-20 summit process, consistency is a criterion that will become harder to satisfy as the G-20's development continues and its agenda expands.

Kwak Soo-jong of SERI wrote of the need for South Korea "to exercise its leadership continuously in the next G-20 summits so that both the Seoul Development Consensus and the global financial safety nets can be further discussed." ${ }^{60}$ For South Korea (and other newcomers to G-20 summitry), ensuring the durability of the G-20 is clearly important: establishing the G20 as the top table of international summitry maintains Korea's already established position at the table, thereby encouraging it to provide the leadership that in turn is supported through domestic political enhancement and promotion of Korea's national brand.

\section{Notes}

Judith Cherry is lecturer in Korean business and management in the School of East Asian Studies at the University of Sheffield. She is the author of Korean Multinationals in Europe (2001) and Foreign Direct Investment in Post-crisis Korea: European Investors and "Mismatched Globalization" (2007).

Hugo Dobson is professor of Japan's international relations in the School of East Asian Studies at the University of Sheffield. He is the author of Japan and the G7/8, 1975-2002 (2004) and The Group of 7/8 (2007), and he is coauthor of Japan's International Relations: Politics, Economics and Security, 3rd ed. (2011).

1. Robert Putnam and Nicholas Bayne, Hanging Together: Cooperation and Conflict in the Seven-Power Summits (London: Sage, 1987), p. 202.

2. John Kirton, "Contemporary Concert Diplomacy: The Seven-Power Summit and the Management of International Order," paper prepared for the annual meeting of the International Studies Association and the British International Studies Associations, 29 March-1 April 1989, London, www.g7.utoronto.ca/scholar /kirton198901/index.html (accessed 27 October 2010).

3. Nicholas Bayne, Staying Together: The G8 Summit Confronts the 21 st Century (Aldershot, UK: Ashgate, 2005), pp. 12-13.

4. Bob Davis, “South Korea: Ready to Lead the G-20?” Wall Street Journal, 28 May 2009.

5. SaKong Il, "Korea and the G-20 Summit Next November," East Asia Forum, 22 November 2009, www.eastasiaforum.org/2009/11/22/korea-and-the-g20 -summit-next-november (accessed 14 May 2012).

6. Stanley White and Linda Sieg, "Japan Questions South Korea G-20 Leadership over FX," Reuters, 13 October 2012, www.reuters.com/article/2010/10/13/us -global-economy-idUSTRE69B14B20101013 (accessed 14 May 2012); Davis, "South Korea."

7. "IMF Gains Sway, but Its Authority Is Uncertain," New York Times, 24 October 2010. 
8. Cho Jin-seo, "Seoul Consensus on Development in Sight," Korea Times, 12 November 2010.

9. Bank for International Settlements, "Update on Basel III Implementation," 18 October 2011, www.bis.org/press/p111018.htm (accessed 4 January 2012).

10. Kim Yong-ki, "The Rise of G-20 and Korea's Response," SERI Quarterly, 10 April 2010, www.seriquarterly.com/03/qt_Section_read.html?mncd=0302\&pub $=20100410 \&$ Falocs $=03 \&$ dep $=2 \&$ pubseq $=149$ (accessed 15 October 2010); Felix Innig, "Upcoming G-20 Summit Could Boost S. Korean GDP by More Than \$20 Billion," International Business Times, 16 September 2010.

11. G-20 Information Centre, "Communiqué: G-20 Leaders Summit," 4 November 2011, www.G20.utoronto.ca/2011/2011-cannes-communique-111104-en.html (accessed 11 January 2012).

12. Lee Myung-bak, "Pittsburgh: Bridging the Washington-London G-20 Summits and Beyond," Munk Centre for International Studies at Trinity College, University of Toronto, September 2009, www.g7.utoronto.ca/newsdesk/pittsburgh/lee.html (accessed 15 December 2010).

13. G-20 Information Centre, "The G-20 Seoul Summit Leaders' Declaration," 12 November 2010, www.G20.utoronto.ca/2010/G20seoul.html (accessed 7 January 2011).

14. G-20, “2011 Report of the Development Working Group,” http://reliefweb.int.

15. Thomas Kalinowski, "Can Korea Be a Bridge Between Developing and Developed Countries in the G-20 and Beyond?" in Thomas Fues and Peter Wolf, eds., G-20 and Global Development: How Can the New Summit Architecture Promote ProPoor Growth and Sustainability? (Bonn: German Development Institute, 2010), p. 87.

16. "G-20 to Tackle US-China Currency Concerns," BBC News, 12 November 2010.

17. Andrew Hickley, "Korea to Chair G-20 Emerging Mkts Panel," GFS News, 20 May 2011, www.gfsnews.com/article/1903/1/Korea_to_chair_G-20_emerging _mkts_panel (accessed 19 December 2011).

18. Edward Bukszar, "Analyzing the US/China Currency Dispute, and Its Impact on Canada" (Vancouver: Jack Austin Centre for Asia Pacific Business Studies, Beedie School of Business, Simon Fraser University, October 2011), http://beedie.sfu.ca/jack-austin-centre/analyzing-the-uschina-currency-dispute-and -its-impact-on-canada.

19. Christian Oliver, "Seoul: S. Korea Looks Forward to Its Own Party," Financial Times, 25 June 2010.

20. Yun Tǒngnyong and O Sǔng-hwan, "Sǒul G-20 chǒngsang hoeǔi kyǒlkkwa-wa hyanghu kwaje" [The Seoul G-20 Summit: Outcomes and Future Issues], KIEP Onǔr-ǔi Segye Kyǒngje [World Economic Update], 23 November, 10, no. 32 (2010): 8.

21. "Korea Hopeful of G-20 Progress on Global Imbalance," Korea Herald, 9 March 2011, www.koreaherald.com/business/Detail.jsp?newsMLId=20110309000851 (accessed 19 December 2011).

22. Yun and O, "The Seoul G-20 Summit."

23. Cho Jin-seo, "Shared Growth Picked as G20 Slogan," Korea Times, 20 July 2010, www.koreatimes.co.kr/www/news/biz/2010/08/301_69842.html (accessed 14 May 2012).

24. SaKong Il, "Looking Toward the 2010 Seoul G-20 Summit," East-West Dialogue, no. 5 (April 2010), www.eastwestcenter.org/fileadmin/stored/pdfs /dialogue005.pdf (accessed 16 May 2012).

25. Yoon Sojung, "G-20 Seoul Summit Ends Successfully," Korea.net, 15 November 2010, www.korea.net/news.do? mode=detail\&guid=51331 (accessed 16 November 2010).

26. SaKong, "Looking Toward the 2010 Seoul G-20 Summit."

27. Cho Jin-seo, "Seoul Consensus on Development in Sight." 
28. Lee Dong-Hun, "The G-20 Seoul Summit: Opportunity to Enhance National Brand," Samsung Economic Research Institute Monthly Focus, no. 10 (3 November 2010).

29. Cho Jin-seo, "G-20 Agenda Analysis 2: IMF Reform," Korea Times, 22 August 2010.

30. Cho Jin-seo, "G-20 Agenda Analysis 3: Basel III Banking Reform," Korea Times, 2 September 2010.

31. "G-20 Agrees Guidelines to Measure Economic Imbalances," BBC News, 15 April 2011, www.bbc.co.uk/news/business-13098537 (accessed 4 January 2012).

32. G-20, "Cannes Summit Final Declaration," 4 November 2011, www.g20-g8 .com/g 8-g20/g20/english/for-the-press/news-releases/cannes-summit-final -declaration.1557.html (accessed 4 January 2012); G-20, "The Cannes Action Plan for Growth and Jobs," 4 November 2011, www.g20-g8.com/g8-g20/g20/english/for -the-press/news-releases/the-cannes-action-plan-for-growth-and-jobs.1556.html (accessed 4 January 2012).

33. Park JiMin, "Looking Back to the G-20 Seoul Summit and Forward to the 2011 G-20 Summit," Financial Services Commission blog, 1 May 2011, http://fsc korea.wordpress.com/2011/05/01/looking-back-to-the-G20-seoul-summit-and -forward-to-the-2011-G20-summit (accessed 19 December 2011).

34. G-20 Information Centre, "2010 G-20 Seoul Summit Interim Compliance Report," 25 August 2011, www.G20.utoronto.ca/compliance/2010seoul-interim /index.html (accessed 11 January 2012).

35. G-20 Information Centre, "The Seoul Summit Document," 12 November 2010, www.G20.utoronto.ca/2010/G20seoul-doc.html (accessed 7 January 2011).

36. "Legacies of the G-20 Seoul Summit," Chosun Ilbo [Chosun Daily], 13 November 2010.

37. Kim Tong, "G-20, FTA and N. Korea," Korea Times, 13 November 2010; Lee Jae-Min, "The G-20 Summit in Seoul and Beyond," Korea Herald, 16 November 2010. 38. "Legacies of the G-20 Seoul Summit."

39. Mark McDonald, "Protesters Rally in Seoul Ahead of G-20 Summit," New York Times, 7 November 2010.

40. Kim Eun-jung, "Activists, Laborers Stage Anti-G-20 Protests in Seoul," Yonhap News, 11 November 2010; Kwon Mee-yoo, “Anti-G-20 Protestors Take to the Streets in Seoul," Korea Times, 11 November 2010.

41. Park Si-soo, "G-20 Summit Unmarred by Violent Rallies," Korea Times, 12 November 2010.

42. Choe Wongi, "The Role of Korea in the G-20 Process and the Seoul Summit," paper prepared for international conference "G20 Seoul Summit: From Crisis to Cooperation," organized by the Korean Association of Negotiation Studies, 20 May 2010, Seoul, Korea, www.g20.utoronto.ca/biblio/choe-kans.pdf (accessed 14 October 2010).

43. On the pros and cons of a G-20 secretariat, see Barry Carin, "A G-20 'NonSecretariat': President Nicolas Sarkozy's Conversations with Philosopher Lao Tzu, Strategist Sun Tzu, and Clio, the Muse of History," in Colin Bradford and Wonhyuk Lim, eds., Global Leadership in Transition: Making the G-20 More Effective and Responsive (Washington, DC: Brookings Institution Press, with the Korean Development Institute, 2011), pp. 275-282.

44. "North Korea May Attempt to Disrupt G-20 Summit, Seoul Warns," Daily Telegraph, 4 October 2010. Brand."

45. Lee Dong-Hun, "The G-20 Seoul Summit: Opportunity to Enhance National

46. Ser Myo-ja, "Korea to Host G-20 Summit in 2010," Joongang Daily, 26 September 2009. 
47. "I taet'ongnyǒng 'Sǒul G-20 sǒngong kyegiro kak punya han tan'gye paltchǒn kidae" [President Lee: "Using the Success of the Seoul G-20 Summit as an Opportunity, I Hope That (South Korea) Will Be Upgraded by One Notch in Every Area"], Maeil Kyŏngje Shinmun [Daily Economic News], 15 November 2010.

48. Hwang Doo-hyong, "S. Korea's G-20 Hosting to Be Equivalent to Seoul Olympics: Scholar," Yonhap News, 26 September 2010; "Bridging Development Gaps," Invest Korea Journal 74, no. 7 (October 2010), www.investkorea.org/Invest KoreaWar/work/journal/content/content_print.jsp?code=4731201.

49. "Korea Relishes Bigger World Role as G-20 Chair," Intellasia.net, 1 March 2010, www.intellasia.net/news/articles/regional/111288027.shtml (accessed 1 October 2010).

50. Choi Chang-bum, "One Great Leap for Korea: The G-20 Seoul Summit," Financial Services Commission, 22 April 2010, http://fsckorea.wordpress.com/2010 /04/22/one-great-leap-for-korea-the-g20-soeul-summit (accessed 1 October 2010).

51. Lee Dong-hwi, "The G-20 in Korea's Diplomacy," Munk Centre for International Studies at Trinity College, University of Toronto, 6 November 2009, www.g20.utoronto.ca/events/lee-091106.html (accessed 11 January 2012).

52. "Legacies of the G-20 Seoul Summit," Chosun Ilbo [Chosun Daily], 13 November 2010.

53. Oh Kongdan, "Korea After G-20 Summit," Korea Times, 13 November 2010.

54. Lee Dong-Hun, "The G-20 Seoul Summit."

55. Kang Seok-ho, "Speaker Park Hee-tae Discusses G-20 Seoul Speakers' Consultation," Arirang News, 17 May 2011, www.arirang.co.kr/News/News_View.asp ?nseq $=116040 \&$ code $=\mathrm{Ne} 3 \&$ category $=4$ (accessed 19 December 2011).

56. Cho Jin-seo, "Seoul Consensus on Development in Sight."

57. Kim Ki-cheon, "The Significance of the 'Seoul Consensus," Chosun Ilbo [Chosun Daily], 16 November 2010.

58. Oh Jun Kyung, "Survey Suggests G-20 Will Improve Korea's Image," Korea.net, 2 November 2010, www.korea.net/detail.do?guid=51059 (accessed 2 November 2010).

59. Lee Myung-bak, "New Year Policy Address to the Nation," Korea.net, 3 January 2011, www.korea.net/detail.do?guid=52374 (accessed 17 January 2011).

60. Kwak Soo-jong, "G-20 Seoul Summit: Achievements and Tasks Ahead," Korea Economic Trends, 22 November 2010, www.seriworld.org/01/wldContL.html ?mn=A\&mncd=0301 (accessed 24 November 2010). 